https://cssr.uitm.edu.my/2018/

5th International Conference on Science and Social Research

Le Meridien Kota Kinabalu Hotel, 5 - 6 December 2018

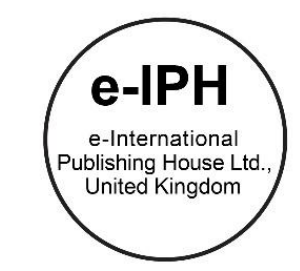

\title{
Postgraduate Students' Perception on their Studies and Supervisors
}

\author{
Teoh Sian Hoon ${ }^{1}$, Geethanjali Narayanan ${ }^{1}$, Gurnam Kaur Sidhu ${ }^{2}$, Priyadarshini Muthukrishnan ${ }^{3}$ \\ ${ }^{1}$ Faculty of Education, Universiti Teknologi MARA Selangor, Puncak Alam, Selangor, Malaysia. \\ 2 Faculty of Education, SEGi University, Kota Damansara, 47810 Petaling Jaya, Selangor, Malaysia. \\ ${ }^{3}$ Department of Education, HELP University, Malaysia .
}

teohsian@uitm.edu.my, geetha@uitm.edu.my, gurnamsidhu213@yahoo.com,priyadarshini.m@help.edu.my

Tel: +603-32584926

\begin{abstract}
Postgraduate candidates need to graduate on time (GOT). Failure to GOT among postgraduates is a loss to the nation. GOT should be analyzed from the postgraduate candidates' perspectives. Therefore, this paper explores postgraduate students' perspectives about their postgraduate studies. An adapted questionnaire survey was utilized to delve into the postgraduates' perspective. This quantitative study involved 66 postgraduate candidates from public institutions of higher learning in Malaysia. Initial findings revealed that the candidates rated their supervisor at a higher rating compared to the skills they possessed. Besides, the correlation between critical reading skills and conceptual with research skills is moderately high.
\end{abstract}

Keywords: postgraduate study, perceptions, skills, supervisory factor, completion of the thesis.

eISSN: 2398-42870 2020. The Authors. Published for AMER ABRA cE-Bs by e-International Publishing House, Ltd., UK. This is an open access article under the CC BYNC-ND license (http://creativecommons.org/licenses/by-nc-nd/4.0/). Peer-review under responsibility of AMER (Association of Malaysian Environment-Behaviour Researchers), ABRA (Association of Behavioural Researchers on Asians) and CE-Bs (Centre for Environment-Behaviour Studies), Faculty of Architecture, Planning \& Surveying, Universiti Teknologi MARA, Malaysia.

DOI: https://doi.org/10.21834/ebpj.v5iSI3.2557

\subsection{Introduction}

All universities around the world are aiming to put their name at the top level. Hence, getting a good ranking becomes more competitive. One of the concerns to achieve this aim is to get a high success rate in graduate on time (GOT). Universities' efforts on GOT have been getting public attention. Besides, many studies reported this issue. Among the numerous studies, about the duration to complete a postgraduate study, Berelson (1960) and Tuckman et al. (1990) had made the comparison by stating that the duration for science-based was lower than non-science-based programs. It was reported that GOT for the sciences was six to seven years and for the social sciences was ten to eleven years. On the other hand, Schuman (2014) and Tuckman et al. (1990) had shared that without considering science or social science, the GOT rate was eight years to 10.5 years. Kinash et al. (2015) believed that the process of GOT should emphasize on the knowledge as well as experience obtained in the duration of the study, which would undoubtedly benefit job advancement. Contrarily, the accomplishment of masters or doctoral studies leads to the extension of candidates' knowledge as well as the efficacy of supervision among postgraduate supervisors (Taylor \& Beasley, 2005). Indirectly, well-monitored candidates will acquire positive skills that can pave the paths to explore various areas (Bozeman \& Feeney, 2007). The supervision is always seen as a source of further improvement for postgraduate research skills. Sidhu, Kaur, Lim, and Chan (2017) suggested that a supervisory system should provide a holistic approach to communication between students and supervisors.

eISSN: 2398-4287○ 2020. The Authors. Published for AMER ABRA cE-Bs by e-International Publishing House, Ltd., UK. This is an open access article under the CC BYNC-ND license (http://creativecommons.org/licenses/by-nc-nd/4.0). Peer-review under responsibility of AMER (Association of Malaysian Environment-Behaviour Researchers), ABRA (Association of Behavioural Researchers on Asians) and cE-Bs (Centre for Environment-Behaviour Studies), Faculty of Architecture, Planning \& Surveying, Universiti Teknologi MARA, Malaysia. DOI: https://doi.org/10.21834/ebpj.v5iSI3.2557 
Therefore, it is essential to ensure that postgraduate students understand themselves so that they can communicate with their supervisors. Besides, they need to understand their abilities in research skills because one-to-one supervision highly depends on the skills and cooperation of students. Students should recognize that the completion of a postgraduate study poses many challenges. Several studies have identified types of skills required for GOT among the postgraduate students as well as types of assistance required from their supervisors for GOT. Among the studies, there were reports highlighted that it was important for supervisors to provide feedback. The feedback could be in terms of building their research skills. Therefore, it is important to investigate the students' research skills as well as their supervisory knowledge that will eventually lead to timely graduation. The research questions in this study are:

(1) What are the postgraduate students' perceptions of their supervisors in completing a thesis?

(2) What are the postgraduate students' perceptions of their skills in completing a thesis?

Thus, this preliminary study explored the expectations of the students regarding their postgraduate studies and their supervisors.

\subsection{Literature Review}

GOT has been included as one of the issues among universities widely. Among the issues, students' matters have been raised for more attention. Sidhu et al. (2017) has pointed out the postgraduate students' roles in GOT succinctly. On the other hand, Burn (2000) illustrated students' skills in writing thesis were related to supervision skills among their supervisors. Among the studies, it was highlighted that students have their responsibilities in the completion of their studies and at the same time their supervisors also played a major role in supporting and assisting their studies. More specifically, the students must track their progress (Manchester University, 2009). On top of this, Akerlind (2008), Lonka (2003), and Mohammad Sadegh (2016) declared that when composing a dissertation, a range of scholarly competences are expected, especially research skills. Defazio et al. (2010) found that while completing their degree programs, the skills are being refined. Lim, Sidhu, Chan, Lee, and Leele Susana Jamian. (2016) noted that with their writing skills, postgraduate students perceived themselves to be moderately ready. Nonetheless, when registering as postgraduate students, the students were in different states of emotion. Students who were highly motivated and ready to encounter all challenges became more skillful in managing their thesis writing compared to their counterparts (Picken, 2017). Nevertheless, their emotional state must be observed. Writing skills can worsen when high expectations of tasks are set. On the other hand, in terms of motivation, the students must keep themselves moving within their structure of studies. The Ph.D. structure of the research was always viewed as a mechanism in which candidates directed themselves despite having thesis supervisors to help them (Pyhältö, Toom, Stubb \& Lonka, 2012). Hence, the students' self-discipline in monitoring themselves became the major factor for them to equip themselves with the ability to GOT. Essentially, oneself who possesses more self-discipline character, they show a high possibility to develop thesis skills as well as to complete tasks on time. Besides, students with sound research skills are categorized as a group of students who have a high opportunity to GOT. However, having qualified thesis supervisors should be emphasized too. For GOT, students are generally advised to work closely with their supervisors who are competent and qualified. Utterly, supervisors' roles for GOT need more attention. By considering students' roles in achieving skills for GOT as well as supervisors' roles in assisting GOT, both students and supervisors need to keep a good connection to develop a wide range of skills efficiently. Besides readiness for a postgraduate study, skills like conceptualizing is crucial in the job market. These abilities are acquired while attending the course of masters or doctoral studies. The candidates who graduate successfully are categorized as self-reliant if they have the principle skills to promote themselves to secure a job. Aside from conceptualization, universities also have identified comprehension and critical thinking skills as important skills especially at the postgraduate level. These skills are all the essence of communication. (Masturah, Sidhu \& Chan, 2013). The employers are having difficulties in obtaining talented staff as not many graduates possess all these skills.

\subsection{Method}

This study examined the postgraduate students' perceptions towards their thesis writing journey. The data from a preliminary study at a government higher learning institution was used in this article. A quantitative survey research design was utilized to investigate the students' perceptions of their studies as well as their supervisors' roles. Meanwhile, the block sampling method was used. The choice of applying the block sampling allocated to the specific groups of students who were in the thesis writing process. The blocks consisted of 5 programs from a public university in Klang Valley. A block was randomly selected. It consisted of 66 respondents. The respondents answered the questionnaire online. According to Fraenkel, Wallen \& Hyun (2010), to establish a significant analysis, a minimum of 50 samples is required. The instrument adapted from Sidhu et. al. (2016) consisted of a few sections, including demographic variables, supervisory factors, student factors, institutional factors, motivational factors, and challenges faced by students. However, this study focused on the student data and the supervisory factors in completing the study. Also, a few abilities were probed, such as communication and decision making, reading, writing, and analytical abilities. Meanwhile, the focus was also on the overall focus of supervision. The respondents responded to the five-point Likert scale survey items online. Two professors verified the validity of the instrument and led to the refinement of the instrument. The reliability check was done using Cronbach's alpha. The instrument has a reliability of $\alpha=0.97$ for students' skills while $\alpha=0.96$ for the supervisor factor. These coefficients are highly reliable as they concur with Cohen, Manion \& Morrission (2007) that the alpha values more than 0.8 are considered highly reliable. 


\subsection{Results}

The following findings are presented based on the research questions. The research questions focus on two main perceptions namely skills for completing thesis and supervisors' involvement.

Table 1 shows that the students rated their supervisors' involvement with a mean of 4.45 (standard deviation $=0.66$ ). The rate is higher than their rating for evaluating their research skills with mean $=3.39$ (standard deviation $=0.77$ ).

Table 1. Descriptive statistics for supervisor factor and skills

\begin{tabular}{lrrrrrrr}
\hline & $\mathrm{N}$ & \multicolumn{1}{c}{ Minimum } & \multicolumn{1}{c}{ Maximum } & \multicolumn{1}{c}{ Mean } & \multicolumn{1}{c}{ Std. Deviation } \\
\hline Supervisor Factors & 66 & 1.50 & 5.00 & 4.45 & .66 \\
\hline Skills (Overall) & 66 & 2.23 & 5.00 & 3.39 & .77 \\
\hline Valid N (listwise) & 66 & & & & \\
\hline
\end{tabular}

\subsection{Findings for research question one: 'What are the postgraduate students' perceptions of their supervisors in completing} a thesis?'

The students' perceptions of their study is the focus of this study. Their perceptions need to be identified from related matters. Perceptions towards their studies in terms of their supervisors are always the focus. The following results indicate the postgraduate students' overall perceptions of their supervisors' supervision. Overall, they rated their supervisors positively with mean=4.45 and standard deviation $=0.66$, as shown in Table 1. Table 2 shows the results of the students' perceptions of supervisors. The respondents highly rated their supervisors as committed (mean $=4.55$, standard deviation $=0.66$ ) and responsible (mean=4.52, standard deviation $=0.73$ ); they were also satisfied that their supervisors' availability (mean $=4.36$, standard deviation $=0.82$ ) and their supervisors motivated them (mean=4.45, standard deviation=0.84). Regarding supervisors' feedback, the postgraduate students reflected that their supervisors provided timely feedback (mean=4.47, standard deviation $=0.66$ ) and provided constructive feedback (mean $=4.44$, standard deviation=0.77). Also, they were happy with their supervisors' concern, they also by rated them high in terms of ensuring them possess adequate research skills (mean $=4.45$, standard deviation $=0.71$ ) and always guiding them (mean $=4.29$, standard deviation $=0.82$ )

Table 2 Descriptive statistics (Supervisor (SV) Factors)

\begin{tabular}{|c|c|c|c|c|c|}
\hline & $\mathrm{N}$ & Minimum & Maximum & Mean & Std. Deviation \\
\hline $\begin{array}{l}\text { SV is knowledgeable in my area of } \\
\text { study }\end{array}$ & 66 & 2.00 & 5.00 & 4.41 & .78 \\
\hline SV is very committed & 66 & 2.00 & 5.00 & 4.55 & .66 \\
\hline SV displays good communication skills & 66 & 3.00 & 5.00 & 4.55 & .68 \\
\hline SV has vast research experience & 66 & 1.00 & 5.00 & 4.41 & .84 \\
\hline SV is responsible and reliable & 66 & 1.00 & 5.00 & 4.52 & .77 \\
\hline SV is an ethical researcher & 66 & 1.00 & 5.00 & 4.55 & .73 \\
\hline SV is always available for consultation & 66 & 1.00 & 5.00 & 4.36 & .82 \\
\hline SV gives timely feedback & 66 & 2.00 & 5.00 & 4.47 & .66 \\
\hline 1 gives constructive feedback & 66 & 1.00 & 5.00 & 4.44 & .77 \\
\hline $\begin{array}{l}\text { SV motivates me to produce quality } \\
\text { work }\end{array}$ & 66 & 1.00 & 5.00 & 4.45 & .84 \\
\hline $\begin{array}{l}\text { SV ensures that I possess adequate } \\
\text { research skills }\end{array}$ & 66 & 2.00 & 5.00 & 4.45 & .71 \\
\hline $\begin{array}{l}\text { SV guides me on how and where to } \\
\text { present/publish }\end{array}$ & 66 & 1.00 & 5.00 & 4.29 & .82 \\
\hline Valid N (listwise) & 66 & & & & \\
\hline
\end{tabular}

\subsection{Findings for research question two: 'What are the postgraduate students' perceptions of their skills in completing a thesis?'}

Table 3 shows a detailed analysis of the overall skills in Table 1. The result in Table 3 indicated that the overall skills shown by the postgraduate students were relatively low, with a mean of 3.39 and a standard deviation of 0.47 . The results were analyzed according to the range in the Likert scale (1 to 5$)$. The skills consisted of four skills that were the focus of this study. The skills were critical reading skills, writing skills, research skills, and conceptual skills. Table 3 displays the investigated skills. The skills were commonly applied among the students, particularly their preparedness to start on their postgraduate journey. Writing skills were recognized as the least gained skill. Similarly, the students also perceived that they possessed limited readiness in terms of critical reading skills. The result indicated that the candidates were not prepared to face all the demands of the studies.

Table 3: Descriptive statistics for each aspect of skills acquired

\begin{tabular}{lccc}
\hline & $\mathrm{N}$ & Mean & Std. Deviation \\
\hline \hline Critical Reading Skills & 66 & 3.39 & 0.54 \\
Writing Skills & 66 & 3.21 & 0.55 \\
Research Skills & 66 & 3.34 & 0.56 \\
Conceptual Skills & 66 & 3.39 & 0.60 \\
\hline
\end{tabular}




\begin{tabular}{llll}
\hline Overall Skills & 66 & 3.39 & 0.47 \\
\hline
\end{tabular}

Table 4 shows that the correlations among the skills. It was reported that the relationships were significantly related. The results presented that research skills and conceptual skills were highly correlated. The correlation coefficient value can be observed from research skills and conceptual skills $(r=0.772$ with $p$-value $<0.05)$. The correlation showed that research skills were moderately correlated with other skills. It was noticed that the research skills were moderately correlated with conceptual skills, critical reading skills, and writing skills. The respective coefficient correlations were $r=0.772, r=0.711$ and $r=0.636$. Also, conceptual skills show moderately high correlation with research skills, critical reading skills, and writing skills. The respective coefficient correlations were $r=0.772$, $r=0.716$ and $r=0.675$.

Table 4: Correlations among the skills

\begin{tabular}{llcccc}
\hline & & $\begin{array}{c}\text { Critical Reading } \\
\text { Skills }\end{array}$ & $\begin{array}{c}\text { Writing } \\
\text { Skills }\end{array}$ & $\begin{array}{c}\text { Research } \\
\text { Skills }\end{array}$ & $\begin{array}{c}\text { Conceptual } \\
\text { Skills }\end{array}$ \\
\hline \hline Critical Reading Skillss & Pearson Correlation & 1 & $.649^{* *}$ & $.711^{* *}$ & $.716^{* *}$ \\
& Sig. (2-tailed) & & .000 & .000 & .000 \\
\hline \multirow{2}{*}{ Writing Skills } & Pearson Correlation & $.649^{* *}$ & 1 & $.636^{* *}$ & $.675^{* *}$ \\
& Sig. (2-tailed) & .000 & & .000 & .000 \\
\hline Research Skills & Pearson Correlation & $.711^{* *}$ & $.636^{* *}$ & 1 & $.772^{* *}$ \\
& Sig. (2-tailed) & .000 & .000 & & .000 \\
\hline Conceptual Skillss & Pearson Correlation & $.716^{* *}$ & $.675^{* *}$ & $.772^{* *}$ & 1 \\
& Sig. (2-tailed) & .000 & .000 & .000 & \\
\hline \hline
\end{tabular}

\subsection{Discussion and Conclusion}

The students were in their first year of postgraduate study. Such students need more guidance from their supervisor as they rated themselves with low and moderate skills (mean $=3.3858$, standard deviation $=0.76653$ ). The students yearned more assistance in their initial step towards a right and successful pathway for their postgraduate journey. Hence, the early nurturing process is expected from the supervisors (Durham, 2017). Specifically, the higher relationships were indicated among the important skills, namely among critical reading skills, writing skills, research skills, and conceptual skills. The relationships were in the range of 0.5 to 0.76 . The results indicated that more time and effort should be focused among the postgraduate students. Specifically, the skills were interrelated. The skills were referred to as research skills and conceptual skills (with $r=0.772$ ). These two skills were partly responsible for GOT. These skills were related to thinking skills like to renew and restore information, rationalize problems as well as clarifying explanations about problems. These skills are necessary for writing, especially in the process of completing the thesis. Descriptively, the postgraduate candidates claimed their weakness was in their writing ability. Hence, to increase the students' ability in writing, other skills were required. From the findings, the correlation of $r=0.716$ between critical reading and conceptual skills and $r=0.711$ between critical reading and research skills were considered moderately high which concurs with the study done by Sidhu et. al. (2016). The inadequacy in critical reading alters the students' proficiency in research and conceptual skills. Therefore, it is crucial to prepare students with the necessary critical reading ability. Figure 1 illustrates the findings. The illustration shows that ability to develop reading skills is vital to develop research skills and conceptual skills. These two skills are required to strengthen and cultivate the writing skill.

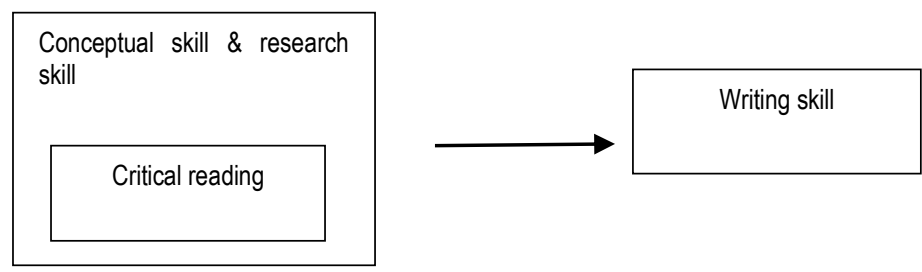

Figure 1: Developing writing skill

Figure 1 coincides with the study done by Lim et al. (2016). On the other hand, the students were not confident with their critical reading skills and rating other skills low. This finding is in tandem with the outcome of Sidhu, Kaur, Lim, and Chan (2016) where many candidates have constraints especially in critical reading ability, which in turn does not help them to start their masters or doctoral journey.

Meanwhile, the importance of academic growth among postgraduate candidates to develop high-quality work was emphasized by Melati Sumari (2004). The development of this skill was emphasized for producing more GOT students. The skill refers to the required skills in conducting academic writing such as writing a thesis. Therefore, the result of this study has defined and showed a significant conceptual understanding of GOT increment. Besides, the results showed that there was a comparatively higher relationship between the important skills, namely conceptual and research skills. As such, the implication of this study is to ensure the research and conceptual skills must be targeted to achieve GOT. In terms of supervisors' skills, the students rated this more than satisfactory. Descriptively, they perceived that their supervisors possess the required research skills. This perception reflected Hockey's (1997) 
finding that majority of postgraduate beginners depend on their supervisors' involvement and assistance to guide them. Thus, they agreed that their supervisors were committed and responsible by guiding and providing them with feedback. They were not confident to rate the skills they possess to complete their study in the early stage, but they were more confident to rate their supervisors' commitment to guide them. Hence, the postgraduate students found that the main challenge to them comes from themselves. They were not ready to present themselves in their study. In short, the students perceived that they have moderate skills to complete their postgraduate studies. They might be more concerned about their ability and skills to complete a task. Besides, they also perceived that their supervisors were ready to supervise them.

\section{Acknowledgments}

This study is part of a larger study and the authors gratefully acknowledge the funding by the Fundamental Research Grant Scheme (FRGS) from the Ministry of Education, Malaysia and Universiti Teknologi MARA (UiTM). Grant: FRGS/1/2016/SSI09/UITM/01/1

\section{References}

Åkerlind, G.S (2008). An academic perspective on research and being a researcher: an integration of the literature. Studies in Higher Education, 33(1), 17-31,

Berelson, B. (1960). Graduate Education in the United States. New York: McGraw-Hill.

Bird, L. (2009). Developing self-regulated learning skills in young students (Unpublished doctoral thesis). Deakin University, Melbourne, Australia

Bowen, W.G., \& Rudenstine, N. L. (1992). In pursuit of the Ph.D. Princeton, NJ: Princeton University Press.

Bozeman, B \& Feeney, MK (2007). Toward a useful theory of mentoring: A conceptual analysis and critique. Administrative and Society, 39(6), 719-739.

Bridgstock, R (2009) The graduate attributes we've overlooked: enhancing graduate employability through career management skills. Higher Education Research \& Development, 28(1), 31-44, DOI: 10.1080/07294360802444347

Burns, R. (2000). Realizing the university in an age of super complexity. Buckingham: Society for Research into Higher Education and Open University Press.

Cohen, L., Manion, L \& K. Morrission (2007), Research Methods in Education (7th, Edition). Routledge

Defazio1, J, Jones, J., Tennant, F. \& Hook, S.A. (2010). Academic literacy: The importance and impact of writing across the curriculum - a case study. Journal of the Scholarship of Teaching and Learning, 10(2), $34-47$

Durham, H (2017) Enhancing the Transitional Experience of Taught Postgraduate Students: A Case Study from an Online Distance Learning Programme in Geographical Information Systems. In: EDULEARN17 Proceedings. EDULEARN17: 9th International Conference on Education and New Learning Technologies, 03-05 Jul 2017, Barcelona, Spain. International Academy of Technology, Education and Development (IATED), pp. 5503-5509. ISBN 978-84-697-3777-4 1

Dweck, C.S., Walton, G.M, \& Cohen, G. (2014). Academic tenacity: Mindsets and skills that promote long-term learning. Bill \& Melinda Gates Foundation.

Eyangu, S., Bagire, V., \& Kibrai, M. (2014). An examination of the completion rate of masters programs at Makerere University Business School. Creative Education, 5(22), 10-16.

Fraenkel, J.R., Wallen, N.E., Hyun, H.H. (2012). How to design and evaluate research in education. NY: McGraw-Hill

Gives, J. E., \& Wemmerus, V. (1986). Developing a model of graduate student degree progress. Paper presented at the annual meeting of the Association for the Study of Higher Education, San Antonio, TX.

Golde, C. M. (1995). Student Descriptions of the Doctoral Student Attrition Process. ASHE Annual Meeting Paper

Hagedorn, L. S., Maxwell, W., \& Hampton, P. (2007). Correlates of retention for African American males in community colleges. In Alan Seidman. Minority student retention: The best of the journal of college student retention: Research, theory \& practice (pp. 7- 27). Amityville, New York: Baywood Publishing Company Inc.

Hockey, (1996). Contractual Solutions to Problems in the Supervision of Ph.D. degrees in the U.K. Studies in Higher Education 21(3), 359-371.

Kearns, H, Gardiner, M, \& Marshall, K (2008). Innovation in Ph.D. completion: the hardy shall succeed (and be happy!). Higher Education Research \& Development, $27(1), 77-89$

Kinash, S., Crane, L., Judd, M-M., Mitchell, K., McLean, M., Knight, C., Dowling, D., \& Schulz, M. (2015). Supporting graduate employability from generalist disciplines through employer and private institution collaboration, report prepared for the Office for Learning and Teaching, Australian Government. Retrieved Jan 2, 2017, from http://graduateemployability.com

Lee, L.F, Gurnam Kaur Sidhu, Chan. Y.F., Narayanan, G. \& Teoh S.H. (2016). Assessing Writing Readiness for Academic Purposes Among Students in Higher Education in Tang and L. Logonnathan (eds.), Assessment for Learning Within and Beyond the Classroom, DOI 10.1007/978-981-10-0908-2-27 (p.327-338).

Lim, P.C., Sidhu, G.K., Chan. Y.F., Lee, L.F, \& Leele Susana Jamian. (2016). Assessing Writing Skills of Postgraduate Students: Perspectives of Supervisors and Supervisees in Tang and L. Logonnathan (eds.), Assessment for Learning Within and Beyond the Classroom, DOI 10.1007/978-981-10-0908-2-27 (p.31-41). 
Lonka, K (2003). Helping doctoral students to finish their theses. In L. Björk, G. Bräuer, L. Rienecker, G. Ruhmann, and P. S. Jørgensen (Eds). Teaching Academic Writing across Europe, pp. 113-131, Kluwer University Press, Dordrecht, The Netherlands.

Masturah Alias, Sidhu, G.K., \& Chan, Y.F. (2013). Unemployed graduate' perceptions of their general communication skills at job interviews. Procedia-Social \& Behaviour Sciences, 90, 324-333

Melati Sumari (2004). Challenges of graduate students. Western Michigan University. Unpublished thesis.

Melin, G., \& Janson, K (2006). What skills and knowledge should a Ph.D. have? Changing preconditions for Ph.D. education and post-doc work. Portland Press Ltd

Miller, M. (1995). ABD Status and Degree Completion: A Student's Perspective. Paper presented at the American Educational Research Association, San Francisco, CA

Mohammad Sadegh Bagheri \& Mohammad Javad Riasati (2016). EFL graduate students' IELTS writing problems and students' and teachers' beliefs and suggestions regarding writing skill improvement. Journal of Language Teaching and Research, 7(1), 198-209.

Murray, N., \& Beglar, D (2009). Inside track: writing dissertation \& thesis. Pearson.

Picken, J. (2017). Attitudes \& Perceptions. In Nancy Borkowski (2017). Organizational Behavior in Health Care. Jones \& Bartlet Publishers.

Pyhältö, K., Toom, A., Stubb, J. and Lonka, K. (2012). Challenges of Becoming a Scholar: A Study of Doctoral Students' Problems and Well-Being. International Scholarly Research Network ISRN Education, 1-12

Schuman, R. (1 Aug 2014). Slate. Company. Retrieved http://www.slate.com/articles/life/education/2014/08/abds_all_but_dissertation_ph_d_candidates_who_can_t_quite_finish.html

Sidhu, G.K., Kaur, S., Chan, Y.F., Lim, P.C., Lee, L.F. \& Leele Susana Jamian (2016). Exploring supervisors' perspectives to enhance postgraduate supervision. In Chan, Y.F., Sidhu, G.K., Lee, L.F.

Narasuman, S \& Shireena Basree. (Eds), $7^{\text {th }}$ International Conference on Learning and Teaching (InCULT 2014) Proceedings: Educate to Innovate. Springer Indexed.p.169-182.

Sidhu, G.K., Kaur, S., Lim, P.C. \& Chan, Y.F. (2016). Assessing the Critical Reading Skills of Postgraduate Students: Perspectives of Supervisors and Supervisees in Tang and L. Logonnathan (eds.), Assessment for Learning Within and Beyond the Classroom, DOI 10.1007/978-981-10-0908-2-27 (p.43-52)

Sidhu, G.K., Kaur, S., Lim, P.C. \& Chan, Y.F. (2017). Developing a framework for postgraduate supervision. In Geok Bee The \& Siew Chee Choy (Eds) Empowering $21^{\text {st }}$ Century Learners through holistic and Enterprising Learning. Springer, Singapore (p. $\left.255-267\right)$.

Siti Nor Amira Baharudin, Munira Murad, \& Nur Hana Hj Mat (2013). Challenges of Adult Learners: A Case study of full-time postgraduates students. Procedia-Social and Behaviour Sciences, 90(10), 772-781.

Stock, W. A., Finegan, T. A., \& Siegfried, J. J. (2009). Completing an economics Ph.D. in five years: let the data speak for themselves. American Economic Review: Papers and Proceedings, 99(2), 624-629.

StudyMalaysia.com (2015). The Malaysian Higher Education System - An Overview. Retrieved Jun 2, 2017, from https://www.studymalaysia.com/education/highereducation-in-malaysia/the-malaysian-higher-education-system-an-overview

Taylor, S., and Beasley, N. (2005), A Handbook for doctoral supervisors. Routledge, London, ISBN 0-415-33545-0

The Kingsbury Center (2017). Persistence is a challenge for learning disabled individuals. Retrieved May 5, 2017, from http://www.kingsbury.org/about/persistence-is-achallenge-for-learning-disabled-individuals/

The University of Manchester (2009). Graduate resource book: personal and professional development for postgraduate researchers.

Tuckman, H., Coyle, S., and Bae, Y. (1990). On-Time to the Doctorate. Washington: National Academy Press.

Vijay Kumar \& Bujang B.K. Huat. (Eds) (2011). A handbook for postgraduate supervision. Universiti Putra Malaysia Press

Yaakob, N. F. \& Ayob, A. M. (2003). Development of graduate education in Malaysia: Prospects for internationalization. Retrieved Jan 5, 2017, from http://mahzan.com. 